\title{
CIVIL RIGHTS GROUPS-THEIR IMPACT UPON THE WAR ON POVERTY
}

\author{
JOHN H. WHEELER*
}

Whether we view the twentieth century's Civil Rights Movement in the United States as an inherent and vibrant force, necessary for survival of the Free Society, or whether we view it as an effort to close the gap between our practices and the Republic's written goals, little doubt remains that, in terms of today's all-out effort to provide the means by which every American will bear a full share of responsibility for the nation's stability, the goals of the Office of Economic Opportunity (OEO) cannot escape similarity to the aims and objectives of present-day Civil Rights organizations. To the same extent, the paths leading to equal opportunity and to proper motivation of the disadvantaged shall continue in most instances to be identical or parallel for both groups.

\section{The First Phase of Civil Rights Activity}

Between 1928 and r954, Civil Rights groups in the United States supported a steady flow of litigation seeking to establish complete freedom of movement in the society for every citizen regardless of his race. It was during this period that, little by little, a long line of decisions by the United States Supreme Court removed an endless number and variety of legal barriers which in former years had accounted for: (I) restricted access to public accommodations used in interstate commerce; (2) racial discrimination at all levels of publicly-supported education; (3) enforcement of racially restrictive covenants in conveyances of real property; (4) exclusion of Negroes from participation in the state primaries of political parties; (5) unequal administration of justice; and (6) many other forms of racial discrimination stemming from "state action" or acts of the federal government and/or its administrative personnel. During the same period, Philip Randolph's march on Washington in I94I was sufficiently convincing to cause President Franklin D. Roosevelt to issue Presidential Order No. 8802, creating the President's Committee on Fair Employment Practices. ${ }^{1}$ Roosevelt's FEPC marked the beginning of a series of orders issued in later years by Presidents Truman, Eisenhower, and Kennedy and designed to provide equal opportunity in employment, in housing and in the armed forces. Establishment of this combination of judicial decree and executive action has been described frequently as the initial phase of the Civil Rights Movement during the

*A.B. 1929, Morehouse College; LL.B. 1947, North Carolina College. President, Mechanics and Farmers Bank, Durham, N.C.

6 Fed. Reg. 3109 (1941). 
twentieth century. It has also been described as the process of getting down in "black and white" on the printed page, the basis for a clear declaration of public policy which guarantees an equal opportunity for every American to seek and to achieve a full measure of success in keeping with his talents and his capacity for growth.

\section{II}

\section{A Second Phase}

A "second phase" of the movement-characterized by direct action beginning with the lunch counter "sit-ins" in February 1960, and climaxed by the massive march on Washington in August $\mathrm{rg}_{3}$-may be regarded in retrospect as the period which prepared the climate of public opinion for acceptance of a large volume of definitive action taken in a relatively short period by the Congress.

\section{III}

\section{A Period of Implementation}

Indeed, the recent passage of significant pieces of legislation supporting (I) the decisions of the Supreme Court and (2) the strong civil rights stand of the executive branch of the government, are ample evidence that the nation has reached a strong and clear consensus regarding the urgent need for eliminating the pockets of poverty and disadvantage which undermine the moral and economic strength of society. It is, therefore, no accident that the President and the Congress, working closely one with the other, have been able to achieve the passage of the Manpower Development and Training Act of $1962 ;^{2}$ the Vocational Education Act of $1963 ;^{3}$ the Civil Rights Act of $1964 ;^{4}$ the Economic Opportunity Act of $1964 ;^{5}$ the Elementary and Secondary Education Act of $1965 ;^{6}$ the Appalachian Regional Development Act ( 1965$) ;^{7}$ the Higher Education Facilities Act of $1965 ;^{8}$ the Voting Rights Act of $1965 ;{ }^{\circ}$ and the Housing and Urban Development Act of $1965 .{ }^{10}$ Passage of the foregoing bills reflects widespread recognition of the increasingly critical manner in which rapid social and economic change inflicts casualties upon families and individuals who are unable, without specific aid, to survive sudden shifts in patterns of housing, education and employment.

It is in the "third phase" or "period of implementation" that the objectives and

\footnotetext{
${ }^{5} 76$ Stat. 23 , as amended, 42 U.S.C. $\$ \$ 2571-620$ (1964).

37 Stat. 403, as amended, 20 U.S.C. $\$ \S$ I5aa, bb, aaa, 35-35n (1964).

178 Stat. 241,42 U.S.C. $\$ 2000 a$ (1964).

578 Stat. 508, 42 U.S.C. $\$ \S 2701-98 \mathrm{r}$ (1964).

79 Stat. 27 (codified in scattered sections of 20 U.S.C.A. (Supp. 1965)).

79 Stat. 5, 40 U.S.C.A. App. A (Supp. I 665 ).

${ }^{8} 79$ Stat. 1219, 20 U.S.C.A. $\$ \$$ I001-144 (Supp. 1965).

- 79 Stat. 437,42 U.S.C.A. $\$ \$ 197 x$, r973-73p (Supp. 1965).

${ }^{10} 79$ Stat. 451 (codified in scattered sections of 12,42 U.S.C.A. (Supp. 1965)).
} 
modus operandi of the antipoverty program and of Civil Rights groups appear to follow parallel or identical lines. Long before passage of the Economic Opportunity Act, ad hoc local groups, with or without help from established Civil Rights groups, were operating their own Head Start and tutoring programs. Many of these efforts came into being as soon as Negro pupils were able to obtain transfers from racially segregated schools to predominantly white elementary and high schools. Before being funded in 1965 by $\mathrm{OEO}$, the Opportunity Industrial Corporation (headed by Leon Sullivan, a militant Negro minister) was doing an outstanding job of adult education, retraining, and job placement in poverty-stricken areas of Philadelphia. Two years ago, this project's waiting list of approximately 10,000 Negroes and whites was in striking contrast to the lack of local interest being shown in a similar program sponsored by the Philadelphia public schools-which, in spite of adequate financing, a skilled staff, and modern training equipment, appeared to have comparatively little empathy with the problems of the disadvantaged.

Other examples of Civil Rights antipoverty activity prior to passage of the Economic Opportunity Act are numerous. The NAACP has, for years, been engaged in the protection of disadvantaged persons from economic pressure-even to the extent of finding adequate financing for sharecroppers and small landowners who have suffered reprisals for trying to register and vote or for seeking to obtain better job opportunities for those who have been caught in the cycle of poverty. The National Urban League has been engaged in successful pilot programs in mobility and retraining through its National Commerce and Industry Council and its "skills bank." And the Southern Regional Council has since 1945 concerned itself with a variety of projects occasioned by the collapse of cotton tenancy and the mechanization of southern farms, which resulted in mass migration of Negro farm workers to urban areas of the South, North, and West. Following the r954 Supreme Court decision in Brown v. Board of Education, ${ }^{11}$ the Council offered its counseling service to southern school boards and superintendents. This service helped smooth the transition to court-enforced school integration; and even today the Council's services have been invaluable in helping public officials and school personnel perform the task of proper planning, within the OEO guidelines, for projects such as Day Care, Head Start, and the Neighborhood Youth Corps.

\section{IV}

\section{OEO Versus "Established Custom"}

It should not be surprising to note the extent to which some governors, mayors, and big city politicians have begun to exhibit varying degrees of hostility to the Johnson administration's "War on Poverty." The U.S. Employment Service, the public schools, public welfare services, vocational training, and other programs funded

${ }^{12} 349$ U.S. 294 (1955). 
in whole or in part by grants from the federal government, have, in the past, been operated by each state according to its own political objectives and local custom. In many instances, provisions of the Civil Rights Act of 1964 and the new guidelines issued with reference to OEO's community action projects and certain auxiliary programs administered by the U.S. Department of Labor, the U.S. Office of Education, the Small Business Administration, the Farmers Home Administration, and other federal agencies are in direct conflict with established policies of existing state agencies operating at the local level. Some communities have long-standing commitments to local industry to maintain a large supply of surplus, unskilled labor. Others are committed to the maintenance of employment preferences which discriminate on the basis of race or class. Still others are responsive to the special demands of the Klan, the White Citizens Councils, and other special groups, or to labor unions which discriminate in their hiring and apprenticeship programs.

In spite of rising adverse pressures upon the antipoverty program by established public agencies and special interests, the impact of Civil Rights groups looms as the strongest and most positive support for the effort to eliminate poverty and disadvantage from the American way of life. The positive impact of the Civil Rights Movement is reflected in the OEO Community Action Guidelines, which set forth a strong policy of nondiscrimination-clearly reflecting the intent of Congress as to the letter and spirit of the law. But for the Civil Rights Movement and its forceful, persistent pressures on the federal government, the Economic Opportunity Act of Ig64 would undoubtedly have followed the traditional pattern of federal legislation and programs. The concepts of maximum feasible participation and involvement of the poor are attributable, at least in part, to the "Movement." The phrases themselves imply the involvement of every element in the community; and, even if the poverty program were to follow the traditional pattern of other federal programs in the South, application of the "maximum feasible participation" rule would guarantee representation from minority groups and from the poor.

In too many instances, there has been conflict between what the letter of the law requires and the manner of implementation, administration, and interpretation of the law at the local level. This distinction has created many problems in the South, because some communities interpret maximum feasible participation to mean the following: (a) "white folks only" (some communities have flatly rejected Negro participation and are not funded); (b) carefully selected "safe" Negroes (primarily school principals or teachers); (c) poor people should be restricted to service in advisory capacities; (d) poor people should not select the representatives from the target areas; (e) blue ribbon whites should decide what's best for the poor people; and (f) members of Civil Rights organizations have no place on the community action agency. Even here, however, the impact of the Civil Rights Movement has been 
strongly felt; through protests and local interpretation of the Economic Opportunity Act itself, the Civil Rights Movement has demonstrated to local communities the intended meaning of the term "maximum feasible participation."

The impact of the Civil Rights Movement is also reflected in the organizational structure of OEO, which requires the employment of a staff person with direct responsibility for implementation of the Civil Rights provisions of the act. The Director of OEO has a Special Assistant for Civil Rights. Now that OEO has become more decentralized, a Special Assistant for Civil Rights is also on the staff of each regional office; and no programs are approved for funding without an examination of civil rights compliance by this special assistant. Such a staff person -with approval and denial authority as to the nondiscriminatory aspect of a given program-is, indeed, a novelty in federal programs.

It is also clear that except for the cooperation of Civil Rights organizations many communities would not today be funded. In fact, $\mathrm{OEO}$ has, in most instances, viewed the participation of Civil Rights organizations in community action programs as indispensable to the funding of local projects. Thus, local politicians and community leaders, heretofore never associated with Civil Rights leaders, have sought them out and asked for their cooperation.

Many communities in the South have never experienced the phenomenon of Negroes and whites talking together about any problem of the community, but poverty program requirements have created biracial organizations in many communities for the first time. Many other progressive changes will no doubt result from biracial discussions of community problems.

Equal employment opportunity in poverty programs, to the extent that it has occurred, is another result of the impact of Civil Rights groups, which have insisted that their support was conditioned upon the employment of qualified Negro personnel. Some communities have stepped up desegregation efforts in order to qualify for poverty funds. This is especially true of the public schools, whose boards have become fearful they will not get Head Start funds unless students and teaching personnel are integrated. The same is true of certain community organizations which have sought to conduct component projects. Before applying to OEO, they have hired Negroes in responsible positions.

The requirements for "maximum feasible participation" and "involvement of the poor" seemed to have met strong resistance from public officials and established public agencies in all parts of the country. This is particularly true in the eleven southern states, where nearly one out of every two persons lives in poverty and where almost one-half of the Ir,300,000 families are classified as "poor." In this region 78.8 per cent of the Negro families are living in poverty as compared with 35.9 per cent of the white families. Forty-four per cent of the poverty in the United States is found in the South, while only one-eighth of the families living in the Northeast and one-seventh of those in the West are poverty-stricken. 
It is interesting to note, however, that the prospect of new federal payrolls in poor counties of the South can produce sharp changes in local custom and traditional attitudes of race. In Coahoma County, Mississippi, the South East Recreation Association-a New Jersey corporation sponsored by an interracial group of citizens, including Baseball Hall of Fame's Jackie Robinson-applied to OEO for a grant of \$27r,000 with which to operate a Head Start program. Immediately thereafter, the Coahoma County Board of Supervisors attempted to pre-empt this application by organizing a community action agency, with a board composed of eight Negroes and eight whites, most of whom were employed by the county school system. In the process of selecting members for the board of directors, it was proposed that neither Sam Luckett, local attorney for the school board and for the White Citizens Council of Clarksdale, nor Aaron Henry, president of the Mississippi Conference Branch of the NAACP, should serve on the board. However, to the surprise of county officials, seven of the eight Negro appointees refused to serve unless Aaron Henry was elected to membership. Thereupon, Governor Paul Johnson sent a personal representative to a Clarksdale meeting between $O E O$ officials and four of the town's leading businessmen. After considerable discussion, it was agreed that Aaron Henry would have to be appointed to membership; and, at the Governor's insistence, it was agreed that Sam Luckett should also be elected to membership. Although the Coahoma County project's board resisted the Governor's recommendation that Luckett and Henry be elected to membership, it finally agreed to elect both of them. The Coahoma County story is typical of many instances throughout the South where strong Civil Rights activity in the community has accounted for the funding of projects which would have suffered certain defeat under ordinary circumstances. Apparently the results stemming from Coahoma's $\$ 242,000$ Head Start program conducted during the summer of $196_{5}$ have been pleasing to the Governor of the state and to a number of young liberals in the Mississippi legislature who have gained a new understanding of the economic and social progress which can be derived from an all-out assault on poverty.

\section{$\mathrm{V}$ \\ Rival Groups}

Although some opponents of the Civil Rights Movement in America have begun to predict the rise of a less militant brand of Negro leadership from the ranks of staff personnel and professionals employed in the "war on poverty," any general clash between Negroes with a Civil Rights background and Negro poverty workers appears unlikely in the foreseeable future. First of all, the successful programs which hire Negroes "across the board" in the full range of salary classifications could not do so without strong Civil Rights support and prodding. Secondly, concerted efforts of some members of Congress to eliminate persons with Civil Rights sympathies or 
backgrounds from employment by the Washington office of OEO have met with negligible, if any, success.

\section{VI \\ WatTS}

Frequently the question has been raised as to whether a concentrated attack upon conditions of poverty could have prevented the devastating riots which have swept the Watts section of Los Angeles twice within recent months. Based upon results obtained in other parts of the country, it appears that an adequately-financed community action program, properly staffed and operated within OEO guidelines, could have done much to change the feeling of hopelessness and despair which triggered the riots. This, however, is not as easy as it sounds in view of the complicated political battle over control of the community action program which had been planned for Los Angeles. To be successful in any given community, the program must be administered by an interracial staff with a firm commitment to the objectives of the war on poverty, and who are supported by a strong board of directors composed of an adequate proportion of persons holding positions of leadership among minorities and among the poor. Many mayors of our leading cities have objected to the election of Negro board members with Civil Rights experience. They have also protested OEO's requirement that representatives of the poor shall be involved as board members in the shaping of policy.

Frustrating and hostile attitudes on the part of officials, labor unions, and major industries in the Los Angeles area have all but discouraged many groups who have tried to accelerate programs of retraining, apprenticeship and on-the-job training since last summer's disturbances. Recently one major industry in the area is said to have imported approximately 1,500 unskilled white workers from the east coast of the United States while refusing to take applications from persons living in Watts. Unless checked by a firm stand on the part of the administration, pressures from entrenched political forces, from industry, and from established public agencies are capable of nullifying the best efforts of OEO to provide an effective program in Los Angeles or any other American city. This probably accounts for the fact that the majority of the cities whose programs are having a measure of success are those in which the Civil Rights leadership either has taken the initiative in establishing the local community action program or has kept a close watch for the resurgence of traditional procedures which, in large part, are responsible for the conditions of disadvantage which make the war on poverty an important item on our agenda for survival. 